\title{
The epidemiology, molecular pathogenesis, diagnosis, and treatment of maturity-onset diabetes of the young (MODY)
}

\author{
Ken Munene Nkonge ${ }^{*^{*}}$ (D), Dennis Karani Nkonge ${ }^{1}$ and Teresa Njeri Nkonge ${ }^{2}$
}

\begin{abstract}
Background: The most common type of monogenic diabetes is maturity-onset diabetes of the young (MODY), a clinically and genetically heterogeneous group of endocrine disorders that affect $1-5 \%$ of all patients with diabetes mellitus. MODY is characterized by autosomal dominant inheritance but de novo mutations have been reported. Clinical features of MODY include young-onset hyperglycemia, evidence of residual pancreatic function, and lack of beta cell autoimmunity or insulin resistance. Glucose-lowering medications are the main treatment options for MODY. The growing recognition of the clinical and public health significance of MODY by clinicians, researchers, and governments may lead to improved screening and diagnostic practices. Consequently, this review article aims to discuss the epidemiology, pathogenesis, diagnosis, and treatment of MODY based on relevant literature published from 1975 to 2020.
\end{abstract}

Main body: The estimated prevalence of MODY from European cohorts is 1 per 10,000 in adults and 1 per 23,000 in children. Since little is known about the prevalence of MODY in African, Asian, South American, and Middle Eastern populations, further research in non-European cohorts is needed to help elucidate MODY's exact prevalence. Currently, 14 distinct subtypes of MODY can be diagnosed through clinical assessment and genetic analysis. Various genetic mutations and disease mechanisms contribute to the pathogenesis of MODY. Management of MODY is subtype-specific and includes diet, oral antidiabetic drugs, or insulin.

Conclusions: Incidence and prevalence estimates for MODY are derived from epidemiologic studies of young people with diabetes who live in Europe, Australia, and North America. Mechanisms involved in the pathogenesis of MODY include defective transcriptional regulation, abnormal metabolic enzymes, protein misfolding, dysfunctional ion channels, or impaired signal transduction. Clinicians should understand the epidemiology and pathogenesis of MODY because such knowledge is crucial for accurate diagnosis, individualized patient management, and screening of family members.

Keywords: Beta cell, Diagnosis, MODY, Monogenic diabetes, Pathogenesis, Prevalence, Treatment

\footnotetext{
* Correspondence: ken.munene@students.uonbi.ac.ke

${ }^{1}$ University of Nairobi, P.O. Box 30197, Nairobi, Kenya

Full list of author information is available at the end of the article
}

(C) The Author(s). 2020 Open Access This article is licensed under a Creative Commons Attribution 4.0 International License, which permits use, sharing, adaptation, distribution and reproduction in any medium or format, as long as you give appropriate credit to the original author(s) and the source, provide a link to the Creative Commons licence, and indicate if changes were made. The images or other third party material in this article are included in the article's Creative Commons licence, unless indicated otherwise in a credit line to the material. If material is not included in the article's Creative Commons licence and your intended use is not permitted by statutory regulation or exceeds the permitted use, you will need to obtain permission directly from the copyright holder. To view a copy of this licence, visit http://creativecommons.org/licenses/by/4.0/ The Creative Commons Public Domain Dedication waiver (http://creativecommons.org/publicdomain/zero/1.0/) applies to the data made available in this article, unless otherwise stated in a credit line to the data. 


\section{Background}

Maturity-onset diabetes of the young (MODY) is the most common type of monogenic diabetes, a clinically and genetically heterogeneous group of endocrine disorders resulting from mutations affecting a single gene involved in pancreatic beta cell function [1]. In 1975, Fajans and Tattersall used the acronym MODY for the first time in the literature to describe a cohort of patients with familial diabetes characterized by autosomal dominant inheritance of a primary defect in insulin secretion [2-4]. Currently, MODY accounts for $1-5 \%$ of all diabetes mellitus cases $[5,6]$. Advancements in molecular diagnostics have led to the identification of 14 distinct subtypes of MODY thus far [7-11]. The most frequently occurring subtypes are attributed to mutations in genes encoding glucokinase (GCK) and hepatocyte nuclear factors (HNFs) [6, 12, 13]. Established treatment options for MODY include various glucoselowering medications such as sulfonylureas, meglitinides, and insulin $[9,10]$. MODY subtypes with progressive beta cell dysfunction may also require long-term management of diabetes-related complications.

The clinical and public health significance of MODY is increasingly being recognized by clinicians, researchers, and governments [14], which may help expand screening and genetic testing capacity. Consequently, this article aims to review current understanding of the epidemiology, pathogenesis, diagnosis, and treatment of MODY based on relevant literature published from 1975 to 2020.

\section{Diagnosis of MODY}

Early-onset diabetes, insulin independence, and autosomal dominant inheritance are traditionally associated with MODY [15]. Age of onset is particularly useful for distinguishing MODY from other types of diabetes. However, MODY subtypes with variable age of onset, low penetrance, or atypical presentation may not fulfill classical diagnostic criteria [15-18]. Furthermore, in a study involving 922 families referred for MODY testing, spontaneous de novo mutations affecting GCK, HNF1A, or HNF4A genes were reported in 11 of the 150 individuals who did not have autosomal dominant inheritance of diabetes mellitus or a multigenerational family history of hyperglycemia [19]. Refinement of the classical diagnostic triad may significantly increase clinical suspicion for MODY and facilitate the process of selecting and referring suspected patients for genetic testing $[15,17,20]$. The refined diagnostic criteria for MODY include: persistent hyperglycemia in early adulthood (typically before 30 years); clinical features incompatible with type 1 or type 2 diabetes mellitus (T1DM, T2DM); diabetes in at least one first-degree relative; evidence of residual pancreatic function; and absence of beta cell autoimmunity.
Currently, there is no concise or standardized diagnostic algorithm for MODY [16]. To address this issue, a systematic approach to the diagnosis of common MODY subtypes is presented in Fig. 1. Overall, a diagnosis of MODY requires a high index of suspicion, clinical assessment, diabetes-specific tests, and comprehensive genetic testing $[15,21]$.

Clinical assessment and comprehensive genetic testing (serial single gene testing or multigene panel) are used to distinguish MODY from other types of diabetes mellitus, guide specific treatment, identify MODY mutations in family members with hyperglycemia, and reduce the risk of complications in asymptomatic family members [4, 21-23]. If genetic testing fails to identify one of the common MODY subtypes, comprehensive genomic testing (chromosomal microarray analysis or exome sequencing) can be used to diagnose rare pathogenic subtypes [24], characterize breakage points of whole gene deletions [25], and identify MODY in patients with clinical features suggestive of contiguous gene deletion syndrome [26, 27]. Nevertheless, the lack of a non-genetic biomarker that accurately identifies patients who have MODY, financial burdens related to cost of genetic tests, and limited access to specialized genetic testing facilities for patients and their families are challenges in clinical practice yet to be fully resolved.

\section{Epidemiology of MODY \\ Estimated incidence}

MODY is usually diagnosed between the second and fifth decades of life [28], yet little is known about the global burden of the condition since population-based studies are seldom conducted. Table 1 presents a summary of the epidemiology of MODY based on available estimates from various countries. The minimum incidence of monogenic diabetes is estimated to be 0.2 cases per 100,000 children and youth below 18 years of age per year [41], while the estimated incidence of MODY is $2.4 \%$ in children and adolescents below 15 years of age with newly diagnosed diabetes mellitus [29]. There are a number of potential explanations for the scarcity of incidence estimates in the literature including: frequent misdiagnosis of MODY due to insidious onset of symptoms; overlap of clinical features with T1DM and T2DM; and low rates of referral for early comprehensive genetic testing due to lack of awareness of MODY among clinicians.

\section{Estimated prevalence}

In contrast to incidence, the estimated prevalence of MODY is widely reported in the literature [31, 32, 39, 42]. The overall prevalence of MODY, mainly from European cohorts, is estimated to be $1-5$ per 10,000 people, accounting for $1-5 \%$ of all diabetes mellitus 


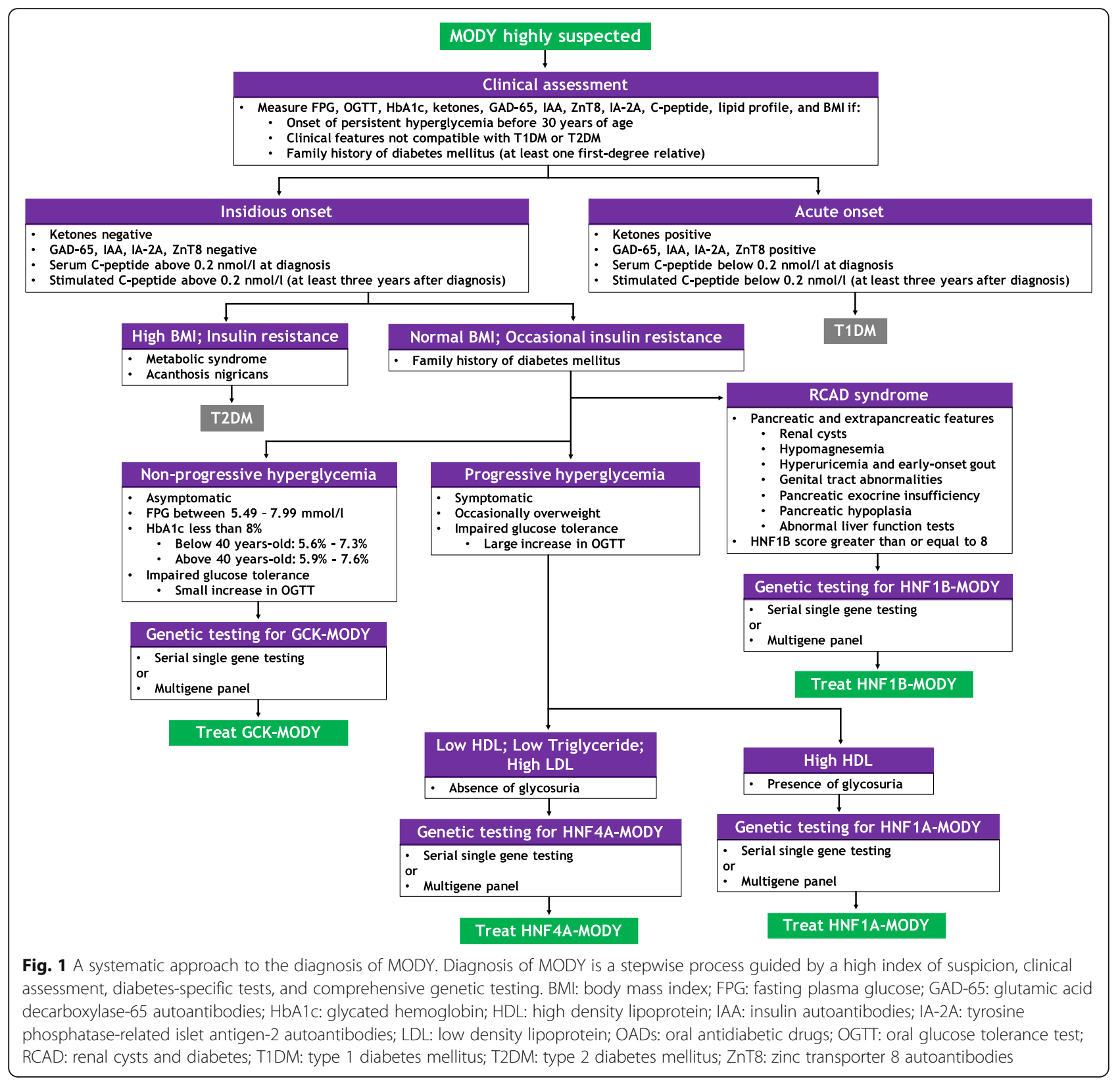

cases $[10,28]$. Current data suggests that prevalence of MODY varies by country [31]. Secondly, despite no reported ethnic predilection, prevalence of MODY varies by ethnicity [31], which may be due to disparities in availability and access to genetic testing [39]. Lastly, the estimated prevalence of MODY is 1 per 10,000 in adults and 1 per 23,000 in children [28], suggesting variation by age.

\section{Prevalence of MODY in the European region}

Due to well-maintained diabetes patient registries and centralized genetic testing facilities, MODY is wellstudied in Europe, particularly the United Kingdom (UK), where monogenic diabetes has an estimated prevalence of $2.5 \%$ and the minimum prevalence of MODY is
68-108 cases per $1,000,000[31,33,43,44]$. The most common subtypes in the UK are HNF1A-MODY (52\% of all genetically confirmed cases), GCK-MODY (32\%), HNF4A-MODY (10\%), HNF1B-MODY (6\%), and Neurogenic differentiation 1 (NEUROD1)-MODY or Insulin (INS)-MODY (less than 1\%) [31, 33]. However, due to poor referral rates for genetic testing, approximately $80 \%$ of MODY cases in the UK are thought to be misdiagnosed as either T1DM or T2DM [33].

Prevalence estimates and MODY subtype distribution for young people living in Norway [34], Netherlands [31, 32], Germany [10, 30], and Poland [31, 45] are comparable to the UK. Importantly, the selection of participants for epidemiologic studies of MODY affects prevalence. 
Table 1 Country-specific incidence and prevalence estimates of MODY

\begin{tabular}{|c|c|c|c|}
\hline Country & Estimated incidence $^{a}$ & Estimated prevalence & References \\
\hline \multicolumn{4}{|l|}{ European region } \\
\hline Germany & $2.4 \%$ & 23.9 per million & {$[29,30]$} \\
\hline Netherlands & - & 30 per million & {$[31,32]$} \\
\hline United Kingdom & - & 68-108 per million & {$[31,33]$} \\
\hline Norway & - & $0.94,6.5 \%$ & {$[34,35]$} \\
\hline Sweden & - & $1.2 \%$ & {$[36]$} \\
\hline Lithuania & - & $3.14 \%$ & [37] \\
\hline Italy & - & $5.5 \%$ & [38] \\
\hline \multicolumn{4}{|c|}{ Non-European region } \\
\hline United States & - & $1.2 \%$ & [39] \\
\hline Australia & - & 89 per million & {$[40]$} \\
\hline
\end{tabular}

${ }^{a}$ The incidence cited is for children and adolescents below 15 years of age with newly diagnosed diabetes mellitus

For example, prevalence of genetically confirmed MODY is higher if autoantibody negative patients are recruited, such as in Norway (6.5\%) [35], Sweden (1.2\%) [36], and Lithuania (3.14\%) [37], or if patients diagnosed with impaired fasting glycemia are included in studies, like in Italy (5.5\%) [38].

\section{Prevalence of MODY in non-European regions}

While the prevalence of MODY in regions outside of Europe remains understudied, available reports suggest geographic and ethnic variation. In the United States, the estimated prevalence of MODY is $1.2 \%$ of all pediatric diabetes mellitus cases and the minimum prevalence of monogenic diabetes in youth below 20 years is estimated to be 21 per 1,000,000 [39]. In Western Australia on the other hand, the prevalence of MODY in diabetic patients below 35 years is $0.24 \%$, which corresponds to an estimated minimum prevalence of 89 cases per 1,000,000 for the entire Australian population [40].

Unfortunately, the prevalence of MODY in African, Asian, South American, and Middle Eastern populations is not known. Clearly, research is needed to elucidate the exact prevalence of MODY in non-European regions. A recent study conducted in Brazil described the first case of NEUROD1-MODY in Latin America and identified a novel frameshift mutation [46], demonstrating that research in countries with multiethnic populations can enhance current understanding of the epidemiology and pathogenesis of MODY.

\section{Molecular pathogenesis and treatment of MODY}

Various types of genetic mutations are implicated in the etiology of MODY [10, 47-49]. Table 2 presents the

Table 2 MODY genes, chromosomal loci, and types of causative mutations

\begin{tabular}{|c|c|c|c|}
\hline Gene & Chromosomal locus & Types of mutations & References \\
\hline HNF4A & $20 q 13.12$ & Missense, frameshift, splice site, nonsense, indel, deletion, insertion & {$[47,49,50]$} \\
\hline HNF1A & $12 q 24.31$ & Missense, frameshift, splice site, nonsense, indel, deletion, insertion & {$[47,49,51]$} \\
\hline PDX1/IPF1 & $13 q 12.2$ & Missense, nonsense, deletion, insertion & {$[47,49,52]$} \\
\hline HNF1B & $17 q 12$ & Missense, frameshift, splice site, nonsense, indel, deletion, insertion & {$[47,49,53]$} \\
\hline NEUROD1 & $2 q 32$ & Missense, frameshift, nonsense, indel, deletion, insertion & {$[47,49,54]$} \\
\hline KLF11 & $2 \mathrm{p} 25$ & Missense & {$[47,49,55]$} \\
\hline PAX4 & $7 q 32$ & Missense, splice site, deletion & {$[47,49,56]$} \\
\hline$B L K$ & $8 p 23$ & Missense & {$[47,49,57]$} \\
\hline GCK & $7 p 13$ & Missense, frameshift, splice site, nonsense, indel, deletion, insertion & {$[47,49,58]$} \\
\hline CEL & $9 q 34$ & Missense, frameshift, indel, deletion, insertion & {$[47,49,59]$} \\
\hline INS & $11 \mathrm{p} 15.5$ & Missense, splice site, nonsense, indel, insertion & {$[47,49,60]$} \\
\hline $\mathrm{ABCC} 8$ & $11 \mathrm{p} 15$ & Missense & {$[47,61,62]$} \\
\hline KCNJ11 & $11 p 15$ & Missense & {$[47,63,64]$} \\
\hline APPL1 & $3 p 14.3$ & Missense, nonsense & {$[49,65,66]$} \\
\hline
\end{tabular}


types of mutations associated with MODY and the affected chromosomes.

Currently, MODY is classified based on the affected gene $[67,68]$. However, a gene-based approach to classification assumes that MODY is one disease entity despite evidence of clinical, genetic, and pathophysiologic heterogeneity among the 14 recognized subtypes. In order to expand the current classification scheme, MODY subtypes can be organized into five categories according to their underlying molecular pathogenesis: transcriptional regulation disorders (dysfunctional nuclear transcription factors); enzyme disorders (dysfunctional or deficient metabolic enzymes); protein misfolding disorders; ion channel disorders (dysfunctional ion channels); and signal transduction disorders. A summary of the molecular pathogenesis and treatment options for MODY is presented in Table 3.

\section{Transcriptional regulation disorders}

\section{HNF4A-MODY (subtype 1)}

The hepatocyte nuclear factor 4 alpha (HNF4A) gene is expressed in liver, pancreatic islets cells and kidney. The HNF4A protein belongs to the steroid/thyroid hormone receptor superfamily of transcription factors and regulates expression of the HNF1A gene, hepatic gluconeogenesis, and lipoprotein biosynthesis [50]. Heterozygous mutations of this gene cause beta cell dysfunction, impaired glucose-stimulated insulin secretion, elevated low-density lipoprotein (LDL), and low levels of highdensity lipoprotein (HDL) and triglyceride [47, 49, 50]. HNF4A-MODY is characterized by fetal macrosomia, transient neonatal hyperinsulinemic hypoglycemia, progressive development of hyperglycemia, and onset of diabetes mellitus in late adolescence or by 25 years of age. Due to the progressive nature of HNF4A-MODY, patients are susceptible to diabetes-related complications. Low carbohydrate diet or low-dose sulfonylureas are used to manage HNF4A-MODY initially but insulin therapy is usually required in advanced disease or during pregnancy $[21,69,70]$. The beneficial role of glucagonlike peptide-1 receptor agonists (GLP-1 RAs) in the management of patients with HNF4A-MODY has recently been reported [75]. Even though this finding is clinically significant, prospective studies are needed to help establish which patients should be offered incretinbased therapy.

\section{HNF1A-MODY (subtype 3)}

The hepatocyte nuclear factor 1 alpha (HNF1A) gene is expressed in liver, pancreas, kidney, and intestine [51, 68]. The HNF1A protein is a member of the homeodomain-containing superfamily of nuclear transcription factors and regulates the expression of the genes that encode insulin (INS), glucose transporter (GLUT) 1 and 2, and sodium/glucose cotransporter 2 (SGLT2) [51, 76]. Heterozygous mutations in the

Table 3 Underlying molecular pathogenesis and treatment of MODY

\begin{tabular}{|c|c|c|c|}
\hline MODY subtype & Pathophysiology & Treatment options & References \\
\hline \multicolumn{4}{|c|}{ Transcriptional regulation disorders } \\
\hline HNF4A (MODY1) & Beta cell dysfunction & Diet, sulfonylureas, insulin & {$[21,69,70]$} \\
\hline HNF1A (MODY3) & Beta cell dysfunction & Diet, sulfonylureas, insulin, GLP-1 RAs & [69] \\
\hline PDX1/IPF1 (MODY4) & Beta cell dysfunction & Diet, OADs, insulin & {$[21,69]$} \\
\hline HNF1B (MODY5) & Beta cell dysfunction & Insulin & {$[21,69,72]$} \\
\hline NEUROD1 (MODY6) & Beta cell dysfunction & Diet, OADs, insulin & {$[21,69]$} \\
\hline KLF11 (MODY7) & Beta cell dysfunction & OADs, insulin & {$[21,69]$} \\
\hline PAX4 (MODY9) & Beta cell dysfunction & Diet, OADs, insulin & {$[21,69]$} \\
\hline BLK (MODY 11) & Insulin secretion defect & Diet, OADs, insulin & {$[21,69]$} \\
\hline \multicolumn{4}{|l|}{ Enzyme disorders } \\
\hline GCK (MODY2) & Glucose sensing defect & Usually not treated. Insulin may be used during pregnancy & {$[69,73,74]$} \\
\hline \multicolumn{4}{|c|}{ Protein misfolding disorders } \\
\hline CEL (MODY8) & Pancreatic exocrine and endocrine dysfunction & OADs, insulin & {$[21,69]$} \\
\hline INS (MODY10) & Insulin biosynthesis defect & Diet, OADs, insulin & {$[21,69]$} \\
\hline \multicolumn{4}{|l|}{ Ion channel disorders } \\
\hline ABCC8 (MODY12) & Insulin secretion defect & Sulfonylureas & {$[21,69]$} \\
\hline KCNJ11 (MODY13) & Insulin secretion defect & Sulfonylureas & {$[21,69]$} \\
\hline \multicolumn{4}{|c|}{ Signal transduction disorders } \\
\hline APPL1 (MODY14) & Insulin secretion defect & Diet, OADs, insulin & {$[21,69]$} \\
\hline
\end{tabular}


HNF1A gene cause progressive beta cell dysfunction, reduced glucose-stimulated insulin secretion, and low renal threshold for glucose (glycosuria) [47, 49, 51, 77]. HNF1A-MODY is typified by transient neonatal hyperinsulinemic hypoglycemia, progressive development of hyperglycemia during childhood, and onset of diabetes mellitus by 25 years of age. Patients with HNF1AMODY are usually at risk of developing diabetes-related complications because glycemic control worsens over time. Low carbohydrate diet or low-dose sulfonylureas are used to manage HNF1A-MODY initially but insulin therapy is required in later stages of the disease or during pregnancy $[21,69,70]$. The use of GLP-1 RAs to effectively manage HNF1A-MODY has been reported [78, 79] and validated in a single-center randomized clinical trial $[71,80]$. Therefore, clinicians may consider treating patients who have HNF1A-MODY with GLP-1 RAs, especially if episodes of hypoglycemia limit the tolerability of sulfonylureas.

\section{PDX1/IPF1-MODY (subtype 4)}

The pancreas/duodenum homeobox 1 (PDX1) protein, also known as IPF1 (insulin promoter factor 1), is a nuclear transcription factor that regulates pancreatic development and beta cell function by activating the expression of glucagon, INS, GLUT2, and GCK genes $[49,81]$. Heterozygous mutations in the PDX1 gene lead to beta cell dysfunction and defective insulin secretion $[47,49,52]$. PDX1-MODY is characterized by diabetes mellitus with variable age of onset (usually between 17 and 67 years) compared to other MODY subtypes [1]. Management options for PDX1-MODY include diet, oral antidiabetic drugs (OADs), and insulin [21, 69].

\section{HNF1B-MODY (subtype 5)}

The hepatocyte nuclear factor 1 beta (HNF1B) protein, also known as transcription factor 2 (TCF2), is a member of the homeodomain-containing superfamily of nuclear transcription factors that regulates organogenesis of the pancreas, liver, genitourinary tract, kidney, intestine, and lungs [47, 82]. Heterozygous mutations cause beta cell dysfunction, hepatic insulin resistance, and a spectrum of congenital malformations termed renal cysts and diabetes (RCAD) syndrome [47, 49, 53, 83]. HNF1BMODY exhibits variable multisystemic phenotypes characterized by a broad spectrum of pancreatic and extrapancreatic clinical manifestations [53, 84, 85]. Typically, renal disease occurs in childhood and diabetes mellitus arises in adolescence or early adulthood, with most affected individuals progressively requiring insulin. Management of HNF1B-MODY involves treatment of renal disease and early intensive insulin therapy to control hyperglycemia and delay the onset of microvascular complications [21, 69, 72].

\section{NEUROD1-MODY (subtype 6)}

The NEUROD1 gene is expressed in pancreatic and neuronal cells and the NEUROD1 protein is a basic helix-loop-helix nuclear transcription factor that regulates expression of the INS gene as well as pancreatic islet morphogenesis and neuronal development [54]. Heterozygous mutations in the NEUROD1 gene cause beta cell dysfunction [47, 49, 54]. NEUROD1-MODY is characterized by variable-onset diabetes mellitus with obese or non-obese phenotypes and occasional ketosis. Management options for NEUROD1-MODY include diet, OADs, or insulin $[21,69]$.

\section{KLF11-MODY (subtype 7)}

The krueppel-like factor 11 (KLF11) gene is expressed in pancreatic islets where it controls the expression of free radical scavengers such as catalase 1 and superoxide dismutase 2 [86]. The KLF11 protein is a zinc-finger nuclear transcription factor that controls beta cell function by acting as a glucose-inducible regulator of INS and PDX1 gene expression [55, 86, 87]. Heterozygous mutations in the KLF11 gene ultimately cause beta cell dysfunction and impaired insulin secretion $[47,49,55,86$, 87]. Clinically, KLF11-MODY presents as early-onset diabetes mellitus and is managed with OADs or insulin $[21,69]$.

\section{PAX4-MODY (subtype 9)}

The paired box gene 4 (PAX4) protein is a nuclear transcription factor that regulates beta cell differentiation and represses the activity of INS and glucagon promoters [88]. Heterozygous mutations in the PAX4 gene cause abnormal beta cell development and lead to beta cell dysfunction and impaired glucose-stimulated insulin secretion $[47,49,56]$. PAX4-MODY is characterized by ketosis-prone diabetes mellitus [89] which is managed with diet, OADs, or insulin $[21,69]$.

\section{BLK-MODY (subtype 11)}

The B-lymphocyte specific tyrosine kinase (BLK) gene is a member of the SRC family of proto-oncogenes that is preferentially expressed in B-lymphocyte and beta cells $[49,57]$. The BLK protein promotes insulin biosynthesis and secretion by upregulating the transcription factors PDX1 and NKX6.1 [57]. Heterozygous mutations in this gene attenuate BLK expression and/or activity resulting in PDX1 and NKX6.1 deficiency, defective glucosestimulated insulin secretion, and reduced beta cell mass $[47,49,57]$. BLK-MODY manifests as diabetes mellitus with an overweight phenotype and is managed with diet, OADs, or insulin [21, 69]. 


\section{Enzyme disorders GCK-MODY (subtype 2)}

The GCK gene is expressed in liver and beta cells [49]. Glucokinase catalyzes adenosine triphosphate (ATP)dependent phosphorylation of glucose to produce glucose-6-phosphate, which is the rate-limiting reaction of glucose metabolism. Heterozygous mutations may either reduce enzymatic activity [90-92] or promote glucokinase misfolding, aggregation, and degradation [9395], leading to defective glucose sensing in beta cells, elevated threshold for glucose-stimulated insulin secretion, and impaired postprandial hepatic glycogen storage [47, $49,58,96]$. GCK-MODY is generally non-progressive and characterized by preserved insulin secretion, mild fasting hyperglycemia present from birth, and minor postprandial glucose excursions. Consequently, this subtype is detected incidentally and treatment with glucose-lowering medications is unnecessary since patients tend to be asymptomatic [21, 69, 73, 97]. However, insulin is indicated during pregnancy to treat maternal hyperglycemia and reduce the risk of fetal macrosomia if serial ultrasound biometry suggests that the fetus has not inherited the maternal GCK mutation [69, 70, 74, 97, 98].

\section{Protein misfolding disorders \\ CEL-MODY (subtype 8)}

The carboxyl-ester lipase (CEL) gene is expressed in acinar cells of the exocrine pancreas where it encodes a bile salt-dependent lipase that is incorporated into pancreatic digestive juice. The carboxyl-ester lipase hydrolyzes cholesterol esters and lipid soluble vitamins in the small intestine. Heterozygous mutations in the CEL gene are associated with early pancreatic atrophy and subsequent exocrine insufficiency, pancreatic lipomatosis, and endocrine dysfunction due to misfolding and cytotoxic aggregation of carboxyl-ester lipase [47, 49, 59, 99-101]. CELMODY presents as adulthood-onset diabetes mellitus and is treated with OADs or insulin [21, 69].

\section{INS-MODY (subtype 10)}

INS-MODY is caused by heterozygous mutations in the gene that encodes preproinsulin, the biologically inactive precursor of the insulin protein. Mutations in the INS gene cause severe misfolding and intracellular accumulation of proinsulin, defective nuclear factor-kappa-lightchain-enhancer of activated B cells (NF-kappa B), and abnormal insulin biosynthesis $[47,49,60]$. Consequently, prolonged endoplasmic reticulum stress activates the terminal unfolded protein response and leads to the induction of beta cell apoptosis. INS-MODY is characterized by reduced beta cell mass, progressive loss of insulin secretion, and variable-onset diabetes mellitus that is managed with diet, OADs, or insulin [21, 69].

\section{Ion channel disorders} ABCC8-MODY (subtype 12)

The ATP-binding cassette transporter subfamily $\mathrm{C}$ member 8 (ABCC8) gene is expressed in the pancreas where it controls the expression of the sulfonylurea receptor 1 (SUR1) subunit of the ATP-sensitive potassium channel found on the beta cell membrane. Opening and closing of the potassium channel regulates glucosestimulated insulin secretion by coupling blood glucose levels and intracellular ATP concentration to the beta cell membrane's electrical activity. Heterozygous mutations affecting the ABCC8 gene disrupt the potassium channel's normal function leading to impaired insulin secretion [47, 61, 62, 102]. ABCC8-MODY may be characterized by congenital hypoglycemic hyperinsulinism, a transient or permanent form of neonatal diabetes mellitus, or adulthood-onset diabetes mellitus [61, 62, 102]. Sulfonylureas are the standard treatment option for ABCC8-MODY [21, 69].

\section{KCNJ11-MODY (subtype 13)}

The potassium channel inwardly rectifying subfamily J member 11 (KCNJ11) gene is highly expressed in the pancreas where it encodes the pore-forming Kir6.2 subunit of the ATP-sensitive potassium channel. Similar to ABCC8-MODY, heterozygous mutations in the KCNJ11 cause defective glucose-stimulated insulin secretion by disrupting the activity of the potassium channel [47, 63, 64, 102]. KCNJ11-MODY may be characterized by congenital hypoglycemic hyperinsulinism, a transient or permanent form of neonatal diabetes mellitus, or late-onset diabetes mellitus [63, 64, 102]. Sulfonylureas are the treatment of choice for KCNJ11-MODY [21, 69].

\section{Signal transduction disorders \\ APPL1-MODY (subtype 14)}

The adaptor protein, phosphotyrosine interaction, $\mathrm{PH}$ domain, and leucine zipper-containing protein 1 (APPL1) gene is highly expressed in skeletal muscle, pancreas, liver, and adipose tissue. The APPL1 protein propagates the insulin signal within cells by interacting with key mediators including Akt serine/threonine kinase 2 (Akt2), insulin receptor substrate (IRS)-1 and IRS2 , and the insulin receptor [65, 103-106]. Additionally, APPL1 controls insulin-stimulated glucose uptake in skeletal muscle and adipose tissue [65, 105]. Heterozygous loss-of-function mutations in this gene lead to defective glucose-stimulated insulin secretion and reduced survival of beta cells $[49,65,66,106]$. APPL1-MODY is a rare subtype and management options include diet, OADs, and insulin $[21,69]$. 


\section{Conclusions}

In conclusion, MODY accounts for $1-5 \%$ of all diabetes mellitus cases. Clinical assessment and comprehensive genetic testing are used to diagnose and classify MODY. Incidence and prevalence estimates for MODY are derived from epidemiologic studies of young people with diabetes who live in Europe, Australia, and North America. Mechanisms involved in the pathogenesis of MODY include defective transcriptional regulation, abnormal metabolic enzymes, protein misfolding, dysfunctional ion channels, or impaired signal transduction. Management of MODY is subtype-specific and established treatment options include diet, oral antidiabetic drugs, or insulin. Clinicians should possess a thorough understanding of the epidemiology and pathogenesis of MODY in order to accurately diagnose patients, individualize patient management and follow-up, and screen family members of affected individuals for diabetes mellitus.

\begin{abstract}
Abbreviations
ABCC8: ATP-binding cassette transporter subfamily C member 8; Akt2: Akt serine/threonine kinase 2; APPL1: Adaptor protein, phosphotyrosine interaction, $\mathrm{PH}$ domain, and leucine zipper-containing protein 1; ATP: Adenosine triphosphate; BLK: B-lymphocyte specific tyrosine kinase; CEL: Carboxyl-ester lipase; GCK: Glucokinase; GLP-1 RAs: Glucagon-like peptide-1 receptor agonists; GLUT: Glucose transporter; HNFs: Hepatocyte nuclear factors; HNF1A: Hepatocyte nuclear factor 1 alpha; HNF4A: Hepatocyte Nuclear Factor 4 alpha; HNF1B: Hepatocyte Nuclear Factor 1 beta; HDL: High-density lipoprotein; INS: Insulin; IPF1: Insulin promoter factor 1; IRS: Insulin receptor substrate; KCNJ11: Potassium channel inwardly rectifying subfamily J member 11; KLF11: Krueppel-like factor 11; LDL: Low-density lipoprotein; NEUROD1: Neurogenic differentiation 1; NFkappa B: Nuclear factor-kappa-light-chain-enhancer of activated B cells; MODY: Maturity-onset diabetes of the young; OADS: Oral antidiabetic drugs; PAX4: Paired box gene 4; PDX1: Pancreas/duodenum homeobox 1; RCAD: Renal cysts and diabetes; SGLT2: Sodium/glucose cotransporter 2; SUR 1: Sulfonylurea receptor 1; TCF2: Transcription factor 2; T1DM: Type 1 diabetes mellitus; T2DM: Type 2 diabetes mellitus; UK: United Kingdom
\end{abstract}

\section{Acknowledgements}

Not applicable.

\section{Authors' contributions}

KMN, DKN, and TNN contributed equally to the content of the review article. DKN and TNN collected relevant articles and undertook literature review. KMN prepared the figure and tables and drafted the manuscript. TNN and DKN critically reviewed and finalized the manuscript. All authors read and approved of the final manuscript.

\section{Funding}

Not applicable.

\section{Availability of data and materials \\ Not applicable.}

Ethics approval and consent to participate

Not applicable.

\section{Consent for publication}

Not applicable.

\section{Competing interests}

The authors declare that they have no competing interests.

\section{Author details}

${ }^{1}$ University of Nairobi, P.O. Box 30197, Nairobi, Kenya. ${ }^{2}$ McMaster University, Hamilton, Ontario L8S 4L8, Canada.

Received: 17 June 2020 Accepted: 26 October 2020

Published online: 04 November 2020

\section{References}

1. Sanyoura M, Philipson LH, Naylor R. Monogenic diabetes in children and adolescents: recognition and treatment options. Curr Diab Rep. 2018;18(8): 58.

2. Tattersall RB, Fajans SS. A difference between the inheritance of classical juvenile-onset and maturity-onset type diabetes of young people. Diabetes. 1975;18(8):44-53.

3. Tattersall R. Maturity-onset diabetes of the young: a clinical history. Diabet Med. 1998;15(1):11-4.

4. Fajans SS, Bell GI. MODY: history, genetics, pathophysiology, and clinical decision making. Diabetes Care. 2011;34(8):1878-84.

5. Kavvoura FK, Owen KR. Maturity onset diabetes of the young: clinical characteristics, diagnosis and management. Pediatr Endocrinol Rev. 2013; 10(2):234-42.

6. Hoffman LS, Jialal I. Diabetes, maturity onset in the young (MODY). In: StatPearls. Treasure Island: StatPearls Publishing; 2019. Available from: https://www.ncbi.nlm.nih.gov/books/NBK532900/.

7. Fajans SS, Bell GI, Polonsky KS. Molecular mechanisms and clinical pathophysiology of maturity-onset diabetes of the young. N Engl J Med. 2001;345(13):971-80

8. Oliveira SC, Neves JS, Perez A, Carvalho D. Maturity-onset diabetes of the young: from a molecular basis perspective toward the clinical phenotype and proper management. Endocrinol Nutr. 2020;67(2):137-47.

9. Urakami T. Maturity-onset diabetes of the young (MODY): current perspectives and treatment. Diabetes Metab Syndr Obes. 2019:12:1047-56.

10. Firdous P, Nissar K, Ali S, Ganai BA, Shabir U, Hassan T, Masoodi SR. Genetic testing of maturity-onset diabetes of the young current status and future perspectives. Front Endocrinol (Lausanne). 2018;9:253.

11. Anik A, Catli G, Abaci A, Bober E. Maturity-onset diabetes of the young (MODY): an update. J Pediatr Endocrinol Metab. 2015;28(3-4):251-63.

12. Baldacchino I, Pace NP, Vassallo J. Screening for monogenic diabetes in primary care. Prim Care Diabetes. 2020;14(1):1-11.

13. Ellard S, Bellanne-Chantelot C, Hattersley AT. Best practice guidelines for the molecular genetic diagnosis of maturity-onset diabetes of the young. Diabetologia. 2008;51(4):546-53.

14. Al-Kandari $\mathrm{H}, \mathrm{Al}$-Abdulrazzaq D, Davidsson L, Al-Mulla F. Maturity-onset diabetes of the young (MODY): a time to act. Lancet Diabetes Endocrinol. 2020;8(7):565-6.

15. Peixoto-Barbosa R, Reis AF, Giuffrida FMA. Update on clinical screening of maturity-onset diabetes of the young (MODY). Diabetol Metab Syndr. 2020; 8(12):50.

16. Urbanová J, Brunerová L, Brož J. Hidden MODY-looking for a needle in a haystack. Front Endocrinol (Lausanne). 2018;9:355.

17. Pinelli M, Acquaviva F, Barbetti F, Caredda E, Cocozza S, Delvecchio M, et al. Identification of candidate children for maturity-onset diabetes of the young type 2 (MODY2) gene testing: a seven-item clinical flowchart (7-iF). Plos One. 2013;8(11):e79933.

18. Lizarzaburu-Robles JC, Gomez-de-la-Torre JC, Castro-Mujica MDC, Vento F, Villanes S, Salsavilca E, et al. Atypical hyperglycemia presentation suggests considering a diagnostic of other types of diabetes: first reported GCKMODY in Perú. Clin Diabetes Endocrinol. 2020;6:3.

19. Stanik J, Dusatkova P, Cinek O, Valentinova L, Huckova M, Skopkova M, et al. De novo mutations of GCK, HNF1A and HNF4A may be more frequent in MODY than previously assumed. Diabetologia. 2014;57(3):480-4.

20. Thanabalasingham G, Pal A, Selwood MP, Dudley C, Fisher K, Bingley PJ, et al. Systematic assessment of etiology in adults with a clinical diagnosis of young-onset type 2 diabetes is a successful strategy for identifying maturity-onset diabetes of the young. Diabetes Care. 2012;35(6):1206-12.

21. Naylor R, Knight Johnson A, del Gaudio D. Maturity-onset diabetes of the young overview. In: Adam MP, Ardinger HH, Pagon RA, et al., editors. GeneReviews. Seattle: University of Washington; 2018. Available from: https://www.ncbi.n/m.nih.gov/books/NBK500456/. 
22. Juszczak A, Pryse R, Schuman A, Owen KR. When to consider a diagnosis of MODY at the presentation of diabetes: aetiology matters for correct management. Br J Gen Pract. 2016;66(647):e457-9.

23. Wedrychowicz A, Tobor E, Wilk M, Ziolkowska-Ledwith E, Rams A, Wzorek K, et al. Phenotype heterogeneity in glucokinase-maturity-onset diabetes of the young (GCK-MODY) patients. J Clin Res Pediatr Endocrinol. 2017;9(3): 246-52

24. Johansson S, Irgens H, Chudasama KK, Molnes J, Aerts J, Roque FS, et al. Exome sequencing and genetic testing for MODY. Plos One. 2012;7(5): e38050.

25. Ellard S, Thomas K, Edghill EL, Owens M, Ambye L, Cropper J, et al. Partial and whole gene deletion mutations of the GCK and HNF1A genes in maturity-onset diabetes of the young. Diabetologia. 2007;50(11):2313-7.

26. Zung A, Petek E, Ben-Zeev B, Schwarzbraun T, Ben-Yehoshua SJ. MODY type 2 in Greig cephalopolysyndactyly syndrome (GCPS) as part of a contiguous gene deletion syndrome. Am J Med Genet A. 2011;155A(10):2469-72.

27. Nagamani SC, Erez A, Shen J, Li C, Roeder E, Cox S, et al. Clinical spectrum associated with recurrent genomic rearrangements in chromosome $17 q 12$. Eur J Human Genet. 2010;18(3):278-84.

28. Owen K. MODY. In: Orphanet; 2014. Available from: https:/www.orpha.net/ consor/cgi-bin/OC_Exp.php?Lng=GB\&Expert=552.

29. Galler A, Stange T, Muller G, Nake A, Vogel C, Kapellen T, et al. Incidence of childhood diabetes in children aged less than 15 years and its clinical and metabolic characteristics at the time of diagnosis: data from the childhood diabetes registry of Saxony. Germany Horm Res in Paediatr. 2010;74(4):28591.

30. Neu A, Feldhahn L, Ehehalt S, Hub R, Ranke MB, et al. Type 2 diabetes mellitus in children and adolescents is still a rare disease in Germany: a population-based assessment of the prevalence of type 2 diabetes and MODY in patients aged 0-20 years. Pediatr Diabetes. 2009;10(7):468-73.

31. Kleinberger JW, Pollin TI. Undiagnosed MODY: time for action. Curr Diab Rep. 2015;15(12):110.

32. Weinreich SS, Bosma A, Henneman L, Rigter T, Spruijt CM, Grimbergen AJ, et al. A decade of molecular genetic testing for MODY: a retrospective study of utilization in the Netherlands. Eur J Hum Genet. 2015;23(1):29-33.

33. Shields BM, Hicks S, Shepherd MH, Colclough K, Hattersley AT, Ellard S. Maturity-onset diabetes of the young (MODY): how many cases are we missing? Diabetologia. 2010;53(12):2504-8.

34. Irgens HU, Molnes J, Johansson BB, Ringdal M, Skrivarhaug T, Undlien DE, et al. Prevalence of monogenic diabetes in the population-based Norwegian childhood diabetes registry. Diabetologia. 2013;56(7):1512-9.

35. Johansson BB, Irgens HU, Molnes J, Sztromwasser P, Aukrust I, Juliusson PB, et al. Targeted next-generation sequencing reveals MODY in up to $6.5 \%$ of antibody-negative diabetes cases listed in the Norwegian childhood diabetes registry. Diabetologia. 2017;60(4):625-35.

36. Carlsson A, Shepherd M, Ellard S, Weedon M, Lernmark A, Forsander G, et al Absence of islet autoantibodies and modestly raised glucose values at diabetes diagnosis should lead to testing for MODY: lessons from a 5-year pediatric Swedish national cohort study. Diabetes Care. 2020;43(1):82-9.

37. Stankute I, Verkauskiene R, Blouin JL, Klee P, Dobrovolskiene R, Danyte E, et al. Systematic genetic study of youth with diabetes in a single country reveals the prevalence of diabetes subtypes, novel candidate genes, and response to precision therapy. Diabetes. 2020;69(5):1065-71.

38. Delvecchio M, Mozzillo E, Salzano G, lafusco D, Frontino G, Patera PI, et al. Monogenic diabetes accounts for $6.3 \%$ of cases referred to 15 Italian pediatric diabetes centers during 2007 to 2012. J Clin Endocrinol Metab. 2017;102(6):1826-34

39. Pihoker C, Gilliam LK, Ellard S, Davelea D, Davis C, Dolan LM, et al. Prevalence, characteristics and clinical diagnosis of maturity onset diabetes of the young due to mutations in HNF1A, HNF4A, and glucokinase: results from the SEARCH for diabetes in youth. J Clin Endocrinol Metab. 2013; 98(10):4055-62

40. Davis TM, Makepeace AE, Ellard S, Colclough K, Peters K, Hattersley A, et al. The prevalence of monogenic diabetes in Australia: the Fremantle diabetes study phase II. Med J Aust. 2017;207(8):344-7.

41. Amed S, Dean HJ, Panagiotopoulos C, Sellers EA, Hadjivannakis S, Laubscher TA, et al. Type 2 diabetes, medication-induced diabetes, and monogenic diabetes in Canadian children: a prospective national surveillance study. Diabetes Care. 2010;33(4):786-91.

42. Sanyoura M, Letourneau L, Knight Johnson AE, Del Gaudio D, Greeley SAW, Philipson LH, Naylor RN. GCK-MODY in the US monogenic diabetes registry: description of 27 unpublished variants. Diabetes Res Clin Pract. 2019;151: 231-6.

43. Shepherd M, Shields B, Hammersley S, Hudson M, McDonald TJ, Colclough $\mathrm{K}$, et al. Systematic population screening, using biomarkers and genetic testing, identifies $2.5 \%$ of the U.K. population with monogenic diabetes. Diabetes Care. 2016;39(11):1879-88.

44. Kropff J, Selwood MP, McCarthy MI, Farmer AJ, Owen KR. Prevalence of monogenic diabetes in young adults: a community-based, cross-sectional study in Oxfordshire. UK Diabetologia. 2011;54(5):1261-3.

45. Fendler W, Borowiec M, Baranowska-Jazwiecka A, Szadkowska A, SkalaZamorowska E, Deja G, et al. Prevalence of monogenic diabetes amongst polish children after a nationwide genetic screening campaign. Diabetologia. 2012:55(10):2631-5.

46. Abreu GM, Tarantino RM, Cabello PH, Zembrzuski VM, da Fonseca ACP, Rodacki $\mathrm{M}$, et al. The first case of NEUROD1-MODY reported in Latin America. Mol Genet Genomic Med. 2019;7(12):e989.

47. Inoue I, Nakaoka H. Genetics of diabetes: are they thrifty genotype? In: Saitou N, editor. Evolution of the human genome l: the genome and genes. Tokyo: Springer; 2018. p. 265-72.

48. Schwitzgebel VM. Many faces of monogenic diabetes. J Diabetes Investig. 2014:5(2):121-33.

49. Online Mendelian Inheritance in Man, OMIM. Maturity-onset diabetes of the young; MODY. Johns Hopkins University, Baltimore. MIM Number: \# 606391: 2016. Available from: https://www.omim.org/entry/606391.

50. Yamagata K, Furuta H, Oda N, Kaisaki PJ, Menzel S, Cox NJ, et al. Mutations in the hepatocyte nuclear factor-4alpha gene in maturity-onset diabetes of the young (MODY1). Nature. 1996;384(6608):458-60.

51. Valkovicova T, Skopkova M, Stanik J, Gasperikova D. Novel insights into genetics and clinics of the HNF1A-MODY. Endocr Regul. 2019;53(2):110-34

52. Macfarlane WM, Frayling TM, Ellard S, Evans JC, Allen LI, Bulman MP, et al. Missense mutations in the insulin promoter factor-1 gene predispose to type 2 diabetes. J Clin Invest. 1999;104(9):R33-9.

53. Lim SH, Kim JH, Han KH, Ahn YH, Kang HG, Ha IS, et al. Genotype and phenotype analyses in pediatric patients with HNF1B mutations. J Clin Med. 2020;9(7):2320.

54. Malecki MT, Jhala US, Antonellis A, Fields L, Doria A, Orban T, et al. Mutations in NEUROD1 are associated with the development of type 2 diabetes mellitus. Nat Genet. 1999;23(3):323-8.

55. Fernandez-Zapico ME, van Velkinburgh JC, Gutierrez-Aguilar R, Neve B, Froguel $P$, Urrutia R, Stein R. MODY7 gene, KLF11, is a novel p300dependent regulator of $\mathrm{Pdx}-1$ (MODY4) transcription in pancreatic islet beta cells. J Biol Chem. 2009;284(52):36482-90.

56. Plengvidhya N, Kooptiwut S, Songtawee N, Doi A, Furuta H, Nishi M, et al. PAX4 mutations in Thais with maturity onset diabetes of the young. J Clin Endocrinol Metab. 2007:92(7):2821-6.

57. Borowiec M, Liew CW, Thompson R, Boonyasrisawat W, Hu J, Mlynarski WM, et al. Mutations at the BLK locus linked to maturity-onset diabetes of the young and beta-cell dysfunction. Proc Natl Acad Sci U S A. 2009;106(34):14460-5.

58. Osbak KK, Colclough K, Saint-Martin C, Beer NL, Bellanne-Chantelot C, Ellard $\mathrm{S}$, Gloyn AL. Update on mutations in glucokinase (GCK), which cause maturity-onset diabetes of the young, permanent neonatal diabetes, and hyperinsulinemic hypoglycemia. Hum Mutat. 2009;30(11):1512-26.

59. Torsvik J, Johansson S, Johansen A, Ek J, Minton J, Raeder H, et al. Mutations in the VNTR of the carboxyl-ester lipase gene (CEL) are a rare cause of monogenic diabetes. Hum Genet. 2010;127(1):55-64.

60. Molven A, Ringdal M, Nordbø AM, Raeder H, Støv J, Lipkind GM, et al. Mutations in the insulin gene can cause MODY and autoantibody-negative type 1 diabetes. Diabetes. 2008;57(4):1131-5.

61. Bowman P, Flanagan SE, Edghill EL, Damhuis A, Shepherd MH, Paisey R, et al. Heterozygous ABCC8 mutations are a cause of MODY. Diabetologia. 2012:55(1):123-7.

62. Huopio H, Otonkoski T, Vauhkonen I, Reimann F, Ashcroft FM, Laakso M. A new subtype of autosomal dominant diabetes attributable to a mutation in the gene for sulfonylurea receptor 1. Lancet. 2003;361(9354):301-7.

63. Bonnefond A, Philippe J, Durand E, Dechaume A, Huyvaert M, Montagne L, et al. Whole-exome sequencing and high throughput genotyping identified KCNJ11 as the thirteenth MODY gene. PLoS One. 2012;7(6):e37423.

64. Yorifuji T, Nagashima K, Kurokawa K, Kawai M, Oishi M, Hosokawa M, et al. The C42R mutation in the Kir6.2 (KCNJ11) gene as a cause of transient neonatal diabetes, childhood diabetes, or later-onset, apparently type 2 diabetes mellitus. J Clin Endocrinol Metab. 2005;90(6):3174-8. 
65. Ivanoshchuk DE, Shakhtshneider EV, Rymar OD, Ovsyannikova AK, Mikhailova SV, Orlov PS, et al. Analysis of APPL1 gene polymorphisms in patients with a phenotype of maturity onset diabetes of the young. J Pers Med. 2020;10(3):E100.

66. Prudente $S$, Jungtrakoon $P$, Marucci A, Ludovico O, Buranasupkajorn $P$, Mazza T, et al. Loss-of-function mutations in APPL1 in familial diabetes mellitus. Am J Hum Genet. 2015;97(1):177-85.

67. Murphy R, Ellard S, Hattersley AT. Clinical implications of a molecular genetic classification of monogenic beta-cell diabetes. Nat Clin Pract Endocrinol Metab. 2008;4(4):200-13.

68. Jang KM. Maturity-onset diabetes of the young: update and perspectives on diagnosis and treatment. Yeungnam Univ J Med. 2020;37(1):13-21.

69. Delvecchio M, Pastore C, Giordano P. Treatment options for MODY patients: a systematic review of literature. Diabetes Ther. 2020;11(8):1667-85.

70. Dickens LT, Naylor RN. Clinical management of women with monogenic diabetes during pregnancy. Curr Diab Rep. 2018;18(3):12.

71. Østoft SH, Bagger J, Hansen T, Pedersen O, Fabe J, Holst JJ, et al. Glucoselowering effects and low risk of hypoglycemia in patients with maturityonset diabetes of the young when treated with a GLP-1 receptor agonist: a double-blind, randomized, crossover trial. Diabetes Care. 2014;37(7):1797805.

72. Warncke K, Kummer S, Raile K, Grulich-Henn J, Woelfle J, Steichen E, et al. Frequency and characteristics of MODY 1 (HNF4A mutation) and MODY 5 (HNF1B mutation): analysis from the DPV database. J Clin Endocrinol Metab. 2019;104(3):845-55.

73. Klupa T, Solecka I, Nowak N, Szopa M, Kiec-Wilk B, Skupien J, et al. The influence of dietary carbohydrate content on glycaemia in patients with glucokinase maturity-onset diabetes of the young. J Int Med Res. 2011;39(6): 2296-301.

74. Dickens LT, Letourneau LR, Sanyoura M, Greeley SAW, Philipson LH, Naylor RN. Management and pregnancy outcomes of women with GCK-MODY enrolled in the US monogenic diabetes registry. Acta Diabetol. 2019;56(4): 405-11.

75. Broome DT, Tekin Z, Pantalone KM, Mehta AE. Novel use of GLP-1 receptor agonist therapy in HNF4A-MODY. Diabetes Care. 2020;43(6):e65.

76. Haliyur R, Tong X, Sanyoura M, Shrestha S, Lindner J, Saunders DC, et al. Human islets expressing HNF1A variant have defective $\beta$ cell transcriptional regulatory networks. J Clin Invest. 2019;129(1):246-51.

77. Yamagata K, Oda N, Kaisaki PJ, Menzel S, Furuta H, Vaxillaire M, et al. Mutations in the hepatocyte nuclear factor-1alpha gene in maturity-onset diabetes of the young (MODY3). Nature. 1996;384(6608):455-8.

78. Docena MK, Faiman C, Stanley CM, Pantalone KM. Mody-3: novel HNF1A mutation and the utility of glucagon-like peptide (GLP)-1 receptor agonist therapy. Endocr Pract. 2014;20(2):107-11.

79. Fantasia KL, Steenkamp DW. Optimal glycemic control in a patient with HNF1A MODY with GLP-1 RA monotherapy: implications for future therapy. J Endocr Soc. 2019;3(12):2286-9.

80. Østoft SH. Incretin hormones and maturity onset diabetes of the young-pathophysiological implications and antidiabetic-treatment potential. Dan Med J. 2015;62(9):B4860.

81. Ahlgren $\mathrm{U}$, Edlund $\mathrm{H}$. Homeodomain proteins in pancreas development. In: Habener JF, Hussain M, editors. Molecular basis of pancreas development and function. New York: Springer; 2001. p. 197-208.

82. Bellané-Chantelot C, Clauin S, Chauveau D, Collin D, Daumont M, Douillard $C$, et al. Large genomic rearrangements in the hepatocyte nuclear factor1 beta (TCF2) gene are the most frequent cause of maturity-onset diabetes of the young type 5. Diabetes. 2005;54(11):3126-32.

83. Faguer S, Chassaing N, Bandin F, Prouheze C, Garnier A, Casemayou A, et al. The HNF1B score is a simple tool to select patients for HNF1B gene analysis. Kidney Int. 2014;86(5):1007-15.

84. Verhave JC, Bech AP, Wetzels JF, Nijenhuis T. Hepatocyte nuclear factor $1 \beta$ associated kidney disease: more than renal cysts and diabetes. J Am Soc Nephrol. 2016;27(2):345-53

85. El-Khairi $R$, Vallier $L$. The role of hepatocyte nuclear factor $1 \beta$ in disease and development. Diabetes Obes Metab. 2016;18(Suppl 1):23-32.

86. Neve B, Fernandez-Zapico ME, Ashkenazi-Katalan V, Dina C, Hamid YH, Joly $E$, et al. Role of transcription factor KLF11 and its diabetes-associated gene variants in pancreatic beta cell function. Proc Natl Acad Sci U S A. 2005; 102(13):4807-12.

87. Lomberk G, Grzenda A, Mathison A, Escande C, Zhang JS, Calvo E, et al. Krüppel-like factor 11 regulates the expression of metabolic genes via an evolutionarily conserved protein interaction domain functionally disrupted in maturity-onset diabetes of the young. J Biol Chem. 2013;288(24):1774558.

88. Smith SB, Ee HC, Conners JR, German MS. Paired-homeodomain transcription factor PAX4 acts as a transcriptional repressor in early pancreatic development. Mol Cell Biol. 1999;19(12):8272-80.

89. Mauvais-Jarvis F, Smith SB, Le May C, Leal SM, Gautier JF, Molokhia M, et al. PAX4 gene variations predispose to ketosis-prone diabetes. Hum Mol Genet. 2004;13(24):3151-9.

90. Galán M, Vincent O, Roncero I, Azriel S, Boix-Pallares P, Delgado-Alvarez E, et al. Effects of novel maturity-onset diabetes of the young (MODY)associated mutations on glucokinase activity and protein stability. Biochem J. 2006;393(Pt 1):389-96.

91. Capuano M, Garcia-Herrero CM, Tinto N, Carluccio C, Capobianco V, Coto I, et al. Glucokinase (GCK) mutations and their characterization in MODY2 children of southern Italy. PLoS One. 2012;7(6):e38906.

92. Valentínová L, Beer NL, Staník J, Tribble ND, van de Bunt M, Hučková M, et al. Identification and functional characterization of novel glucokinase mutations causing maturity-onset diabetes of the young in Slovakia. Plos One. 2012;7(4):e34541.

93. Cho EH, Min JW, Choi SS, Choi HS, Kim SW. Identification of maturity-onset diabetes of the young caused by glucokinase mutations detected using whole-exome sequencing. Endocrinol Metab (Seoul). 2017;32(2):296-301.

94. Negahdar M, Aukrust I, Molnes J, Solheim MH, Johansson BB, Sagen JV, et al. GCK-MODY diabetes as a protein misfolding disease: the mutation R275C promotes protein misfolding, self-association and cellular degradation. Mol Cell Endocrinol. 2014;382(1):55-65.

95. Negahdar M, Aukrust I, Johansson BB, Molnes J, Molven A, Matschinsky FM, et al. GCK-MODY diabetes associated with protein misfolding, cellular selfassociation and degradation. Biochim Biophys Acta. 2012;1822(11):1705-15.

96. Froguel $P$, Vaxillaire $M$, Sun $F$, Velho $G$, Zouali $H$, Butel MO, et al. Close linkage of glucokinase locus on chromosome $7 p$ to early-onset non-insulindependent diabetes mellitus. Nature. 1992;356(6365):162-4.

97. Chakera AJ, Steele AM, Gloyn AL, Shepherd MH, Shields B, Ellard S, et al. Recognition and management of individuals with hyperglycemia because of a heterozygous glucokinase mutation. Diabetes Care. 2015;38(7):1383-92.

98. Rudland VL. Diagnosis and management of glucokinase monogenic diabetes in pregnancy: current perspectives. Diabetes Metab Syndr Obes. 2019;12:1081-9.

99. Raeder H, Johansson S, Holm PI, Haldorsen IS, Mas E, Sbarra V, et al. Mutations in the CEL VNTR cause a syndrome of diabetes and pancreatic exocrine dysfunction. Nat Genet. 2006;38(1):54-62.

100. Johansson BB, Torsvik J, Bjørkhaug L, Vesterhus M, Ragvin A, Tjora E, et al. Diabetes and pancreatic exocrine dysfunction due to mutations in the carboxyl ester lipase gene-maturity onset diabetes of the young (CELMODY): a protein misfolding disease. J Biol Chem. 2011;286(40):34593-605.

101. Dalva M, Lavik IK, El Jellas K, Gravdal A, Lugea A, Pandol SJ, et al. Pathogenic carboxyl ester lipase (CEL) variants interact with the normal CEL protein in pancreatic cells. Cells. 2020;9(1):244.

102. De Franco E, Saint-Martin C, Brusgaard K, Knight Johnson AE, Aguilar-Bryan $L$, Bowman $P$, et al. Update of variants identified in the pancreatic $\beta$-cell $\mathrm{K}_{\text {ATP }}$ channel genes KCNJ11 and ABCC 8 in individuals with congenital hyperinsulinism and diabetes. Hum Mutat. 2020;41(5):884-905.

103. Saito T, Jones CC, Huang S, Czech MP, Pilch PF. The interaction of Akt with APPL1 is required for insulin-stimulated Glut4 translocation. J Biol Chem. 2007;282(44):32280-7.

104. Ryu J, Galan AK, Xin X, Dong F, Abdul-Ghani MA, Zhou L, et al. APPL1 potentiates insulin sensitivity by facilitating the binding of IRS1/2 to the insulin receptor. Cell Rep. 2014;7(4):1227-38.

105. Cheng KK, Lam KS, Wu D, Wang Y, Sweeney G, Hoo RL, et al. APPL1 potentiates insulin secretion in pancreatic $\beta$ cells by enhancing protein kinase Akt-dependent expression of SNARE proteins in mice. Proc Natl Acad Sci U S A. 2012;109(23):8919-24.

106. Schenck A, Goto-Silva L, Collinet C, Rhinn M, Giner A, Habermann B, et al. The endosomal protein Appl1 mediates Akt substrate specificity and cell survival in vertebrate development. Cell. 2008;133(3):486-97.

\section{Publisher's Note}

Springer Nature remains neutral with regard to jurisdictional claims in published maps and institutional affiliations. 